\title{
AIRBORNE RADIO ECHO-SOUNDING IN SHIRASE GLACIER DRAINAGE BASIN, ANTARCTICA
}

\author{
by \\ S. Mae \\ (Department of Applied Physics, Faculty of Engineering, Hokkaido University, Sapporo 060, Japan)
}

and

M. Yoshida

(National Institute of Polar Research, Tokyo 173, Japan)

\section{ABSTRACT}

Airborne radio echo-sounding was carried out in order to measure the thickness of the ice sheet in the Shirase Glacier drainage basin and map the bedrock topography. It was found that the elevation of bedrock was approximately at sea-level from Shirase Glacier to $100 \mathrm{~km}$ up-stream of the glacier and thereafter it was $500-100 \mathrm{~m}$ higher. Investigation of the echo intensity reflected from the bedrock indicates that at ice thicknesses less than $1000 \mathrm{~m}$ absorption was about $5.2 \mathrm{~dB} / 100 \mathrm{~m}$, but at greater ice thicknesses echo intensity did not depend upon the ice thickness but became approximately constant. Where ice thicknesses were greater than $1000 \mathrm{~m}$ in the main flow area of the Shirase Glacier drainage basin, the reflection strengths of about $9 \mathrm{~dB}$ were greater than outside the basin. Since the increase in echo intensity was considered to be due to the existence of water, the strong echo observed in the main part of the basin supported an hypothesis that the base of the basin was wet and the ice sheet was sliding on the bedrock.

\section{INTRODUCTION}

In 1974 the Japanese Antarctic Research Expedition (JARE) established a $150 \mathrm{~km}$ trilateration network, which was tied to Motoi Nunatak in the Yamato Mountains in order to measure the flow of the Shirase Glacier drainage basin (Fig.1). JARE re-surveyed the network and obtained horizontal and vertical velocities (Naruse 1978). Based on these data, Naruse (1978) found that the ice sheet was thinning at a rate of $0.7 \mathrm{~m} \mathrm{a}^{-1}$ along the network only in the Shirase Glacier drainage basin.

Mae and Naruse (1978) and Mae (1979a, b) calculated the basal sliding velocity, $v_{b}$, along the network from the thinning rate, using an equation of continuity, and obtained $\mathrm{v}_{\mathrm{b}} \simeq 10 \mathrm{~m} /$ year - about half of the horizontal flow velocity. They considered that such a large basal sliding velocity was caused by the presence of water at the base of ice sheet. Mae (1979a, b) concluded that the ice sheet in the Shirase Glacier drainage basin was not in a steady state by comparing similar changes of basal shear stress along the flow line in the Shirase Glacier drainage basin with those of surging glaciers. He proposed an hypothesis that the area of the wet base which caused the ice-sheet thinning had been initiated at Shirase Glacier (Fig.1) and had expanded up-stream from Shirase Glacier, reaching the position of the trilateration network a few hundred years ago.

In order to obtain more information on the ice dynamics of the Shirase Glacier drainage basin, JARE planned a 5-year project on glaciology, named Glaciological Programme in East Queen Maud Land, which began in 1982. JARE installed many JMR positioning stations in the basin to measure the velocity of the ice sheet and changes in the ice thickness. The programme of measurement and analysis will be completed in a few years.

Since the dynamics of the ice sheet depends upon ice thickness and the bedrock topography, JARE developed a $179 \mathrm{MHz}$ airborne radio echo-sounder which was installed in a Pilatus Porter PC-6 aircraft. In 1979, the sounder was

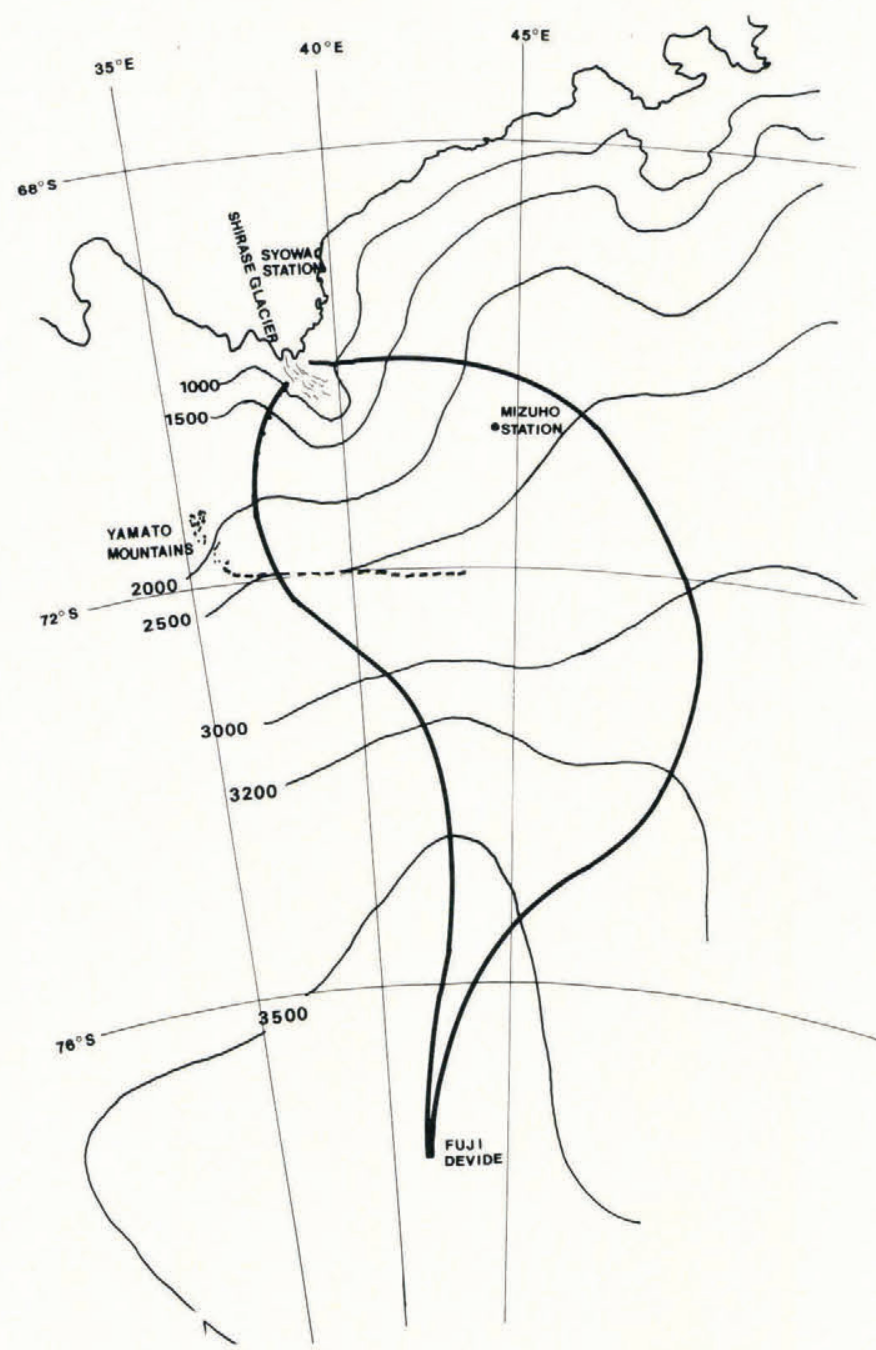

Fig.1. Map of the Shirase Glacier drainage basin (thick solid line). The trilateration network is indicated by a dashed line. 
used to make a preliminary sounding of Shirase Glacier and the Yamato Mountains. At that time the aircraft possessed poor naviagational instruments and the position of the aircraft was determined only by map reading. The sounding flight passed over as many known sites (e.g. nunataks or exposed rocks) as possible. On the basis of these data, Wada and others (1982) made a bedrock-topography map in the vicinity of the Yamato Mountains, but it proved impossible to map the bedrock elevations near Shirase Glacier due to poor navigation. In 1983, JARE carried out further airborne radio echo-sounding using an Omega navigation system. A preliminary report of the sounding was published by Mae (1986), and in this paper the results obtained will be reported in detail.

\section{INSTRUMENTS AND SOUNDING AREA}

Since the $179 \mathrm{MHz}$ sounder was designed to be installed in the small (Pilatus Porter PC-6) aircraft, electric power and aerial dimensions were limited. The peak transmitter power was restricted to about $1 \mathrm{~kW}$ and aerials, $1 \mathrm{~m}$ in length, were attached to the wings of the aircraft. These limited the depth of penetration to $1500-2000 \mathrm{~m}$. The details of the sounder have been reported by Wada and Mae (1981) and Wada and others (1982), and its specifications are listed in Table I. The previous recording system of A-scopes was changed from a $35 \mathrm{~mm}$ camera to a video set.

The radio echo-sounding was carried out in November 1983 along the routes shown in Fig.2. Flight lines 4, 5, 6, and 7 are in the Shirase Glacier drainage basin.

The up-stream area of the Shirase Glacier drainage basin was not surveyed because of logistics difficulties in supporting the aircraft. At present, only oversnow vehicles can survey this up-stream area. In this paper, therefore, only the results of the radio echo-sounding along the routes shown in Fig. 2 are discussed.
TABLE I. SPECIFICATIONS OF SOUNDER

$\begin{array}{cll}\text { Transmitter } & \text { Carrier frequency } & 179 \mathrm{MHz} \\ & \text { Pulse width } & 0.3 \mu \mathrm{s} \\ & \text { Rise time } & 0.15 \mu \mathrm{s} \\ & \text { Peak power } & 1 \mathrm{~kW} \\ & \text { Pulse-repetition frequency } & 1 \mathrm{kHz} \\ & \text { Total power consumption } & \mathrm{dc} 28 \mathrm{~V}, 2.7 \mathrm{~A} \\ & \text { RF gain } & 39 \mathrm{~dB} \\ & & \\ \text { Receiver } & \text { Central frequency } & 179 \mathrm{MHz} \\ & \text { Band width } & 5 \mathrm{kHz} \\ & \text { Noise } & 3 \mathrm{~dB} \\ & \text { Receiver sensitivity } & -104 \mathrm{dBm} \\ \text { Aerials } & & \\ & \text { 3-element Yagi } & 8 \mathrm{~dB} \\ \text { Absolute power gain } & \\ \text { Monitor and } & \text { Oscilloscope (National VP-5260) } \\ \text { recorder } & \text { Rise time: 35 ns } & \\ & \text { Video set } & \end{array}$

\section{RESULTS}

\section{Bedrock topography}

In order to estimate ice thickness, the wave velocity in ice of $169 \mathrm{~m} \mathrm{us}^{-1}$ (Robin and others 1969) was used. Surface-elevation data for the Mizuho Plateau area, including the Shirase Glacier drainage basin, were compiled by Moriwaki of the Japanese National Institute of Polar Research and the bedrock topography was obtained by subtraction of the ice thicknesses.

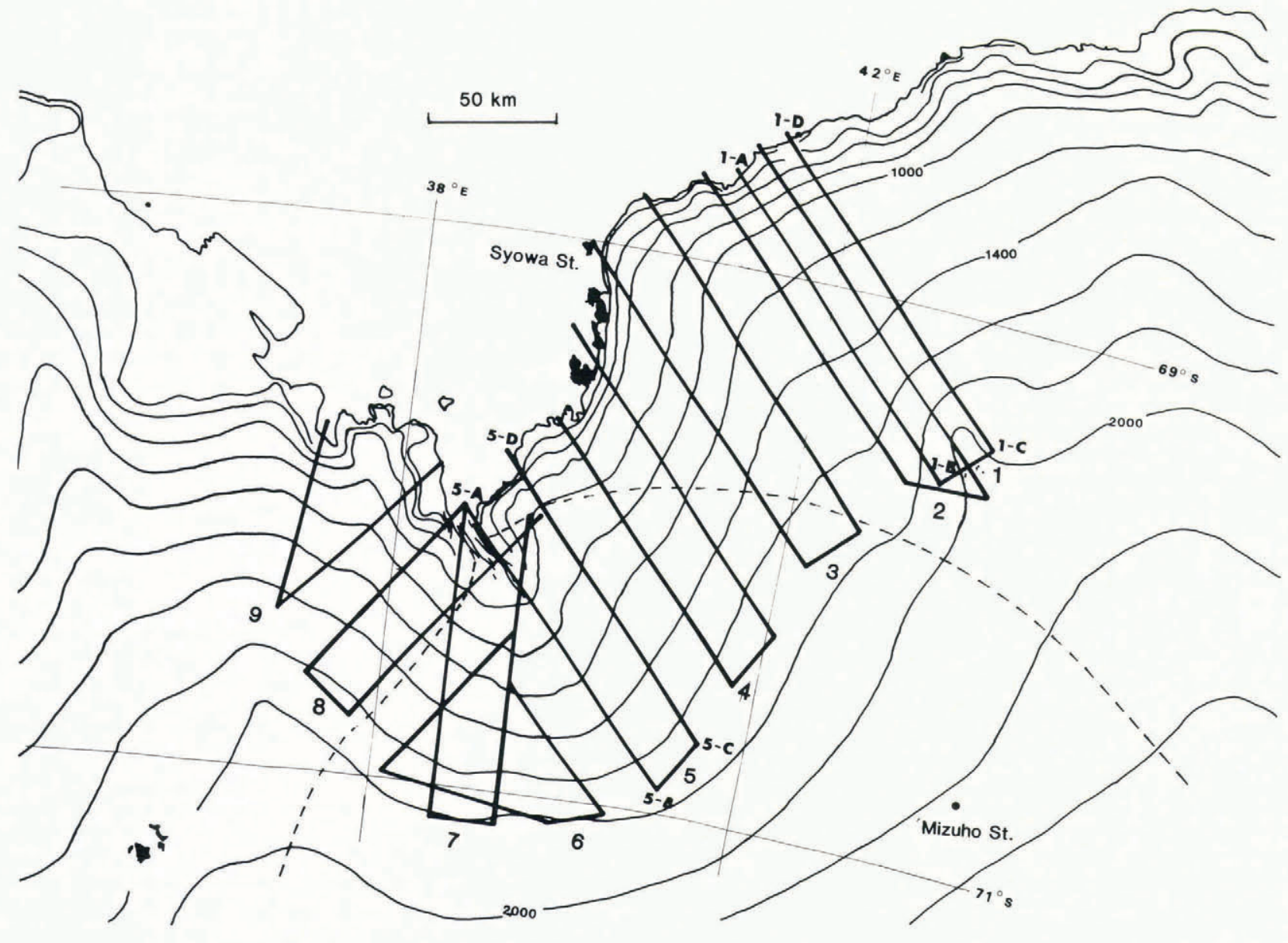

Fig.2. Radio echo-sounding flight lines (thick solid lines). 



Fig.3a. Bedrock topography (thick lines) and surface topography (thin line) of flight 1. b. Bedrock topography (thick lines) and surface topography (thin line) of flight 5.

The elevation of the ice surface and the bedrock along flights 1 and 5 are shown in Fig.3a and b. The elevations of the bedrock surface are at sea-level or higher. On the basis of these results, a contour map of bedrock elevation was compiled and this is shown in Fig.4.

Fig.3a and Fig. 4 indicate that there are subglacial mountains at the up-stream edge of flights 1 and 2 which are about $2000 \mathrm{~m}$ above sea-level. The presence of the mountains had been previously assumed from areas of bareice field with many crevasses and containing rock debris. In the Shirase Glacier drainage basin there are not such high subglacial mountains. From Fig.4 it can be seen that a shallow and wide valley lies between Shirase Glacier and Mizuho Station. Even in this basin, the elevation of the bedrock on the upstream side of the sounding area is about $500 \mathrm{~m}$ above sea-level. This is consistent with the result obtained from a $60 \mathrm{MHz}$ radio echo-sounding survey of an oversnow traverse from Mizuho Station to the Yamato mountains (Shimizu and others 1978; Nishio, private communication). It can be assumed that the bedrock elevation is $500-1000 \mathrm{~m}$ above sea-level in the up-stream area of the Shirase Glacier drainage basin (personal communication from M. Yoshida).

\section{Echos reflected from bedrock}

The intensity, $E$, of the reflected echo from the bedrock surface varies with ice thickness. As shown in
Fig.5a and b, E decreases in proportion to the increase of ice thickness, h, up to $1000 \mathrm{~m}$, thereafter $\mathrm{E}$ is approximately constant.

When $h$ is less than $1000 \mathrm{~m}, \mathrm{E}$ (in $\mathrm{dB}$ ) along flight 1 is given by

$$
E=-0.0052 h-26 .
$$

and $\mathrm{E}$ along flight 5 is given by

$$
E=-0.0052 h-25 \text {. }
$$

Since Equations (1) and (2) are approximately the same, the characteristic feature of the reflection from bedrock shows little difference between the Shirase Glacier drainage basin and the surrounding area. If the reflection coefficient at the bedrock surface is uniform, the absorption within the ice mass is estimated to be $5.2 \mathrm{~dB} / 100 \mathrm{~m}$. This value is larger than $4.5 \mathrm{~dB} / 100 \mathrm{~m}$ obtained by Robin and others (1969) in Greenland.

At ice thicknesses greater than $1000 \mathrm{~m}$, E does not depend on $h$ and becomes approximately constant. The value of $E$ in the Shirase Glacier drainage basin, $(\simeq-78 \mathrm{~dB})$ is larger than in the surrounding area $(\approx-87 \mathrm{~dB})$. It is difficult to explain the difference, $9 \mathrm{~dB}$. It is not clear, if water exists at a base, where there are high hydrostatic pressures of about $15-20 \mathrm{MPa}$ and how such water may influence the dielectric properties of ice at radio frequencies.

The spatial distribution of $\mathrm{E}$ is illustrated in Fig.6. In the Shirase Glacier drainage basin $\mathrm{E}$ at $\mathrm{A}$ and $\mathrm{C}$ is smaller 


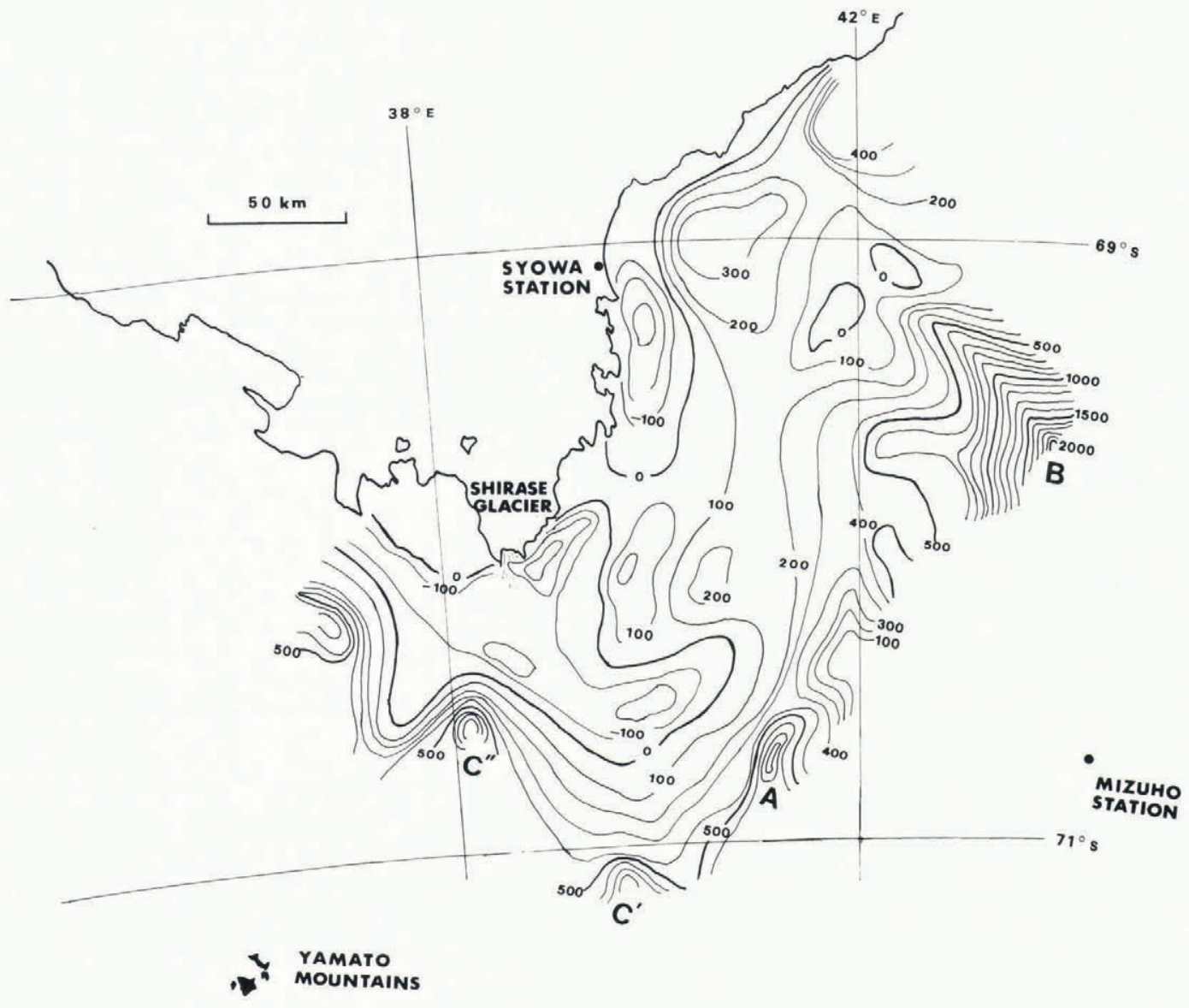

Fig.4. Map of bedrock topography.

$\stackrel{m}{0}$

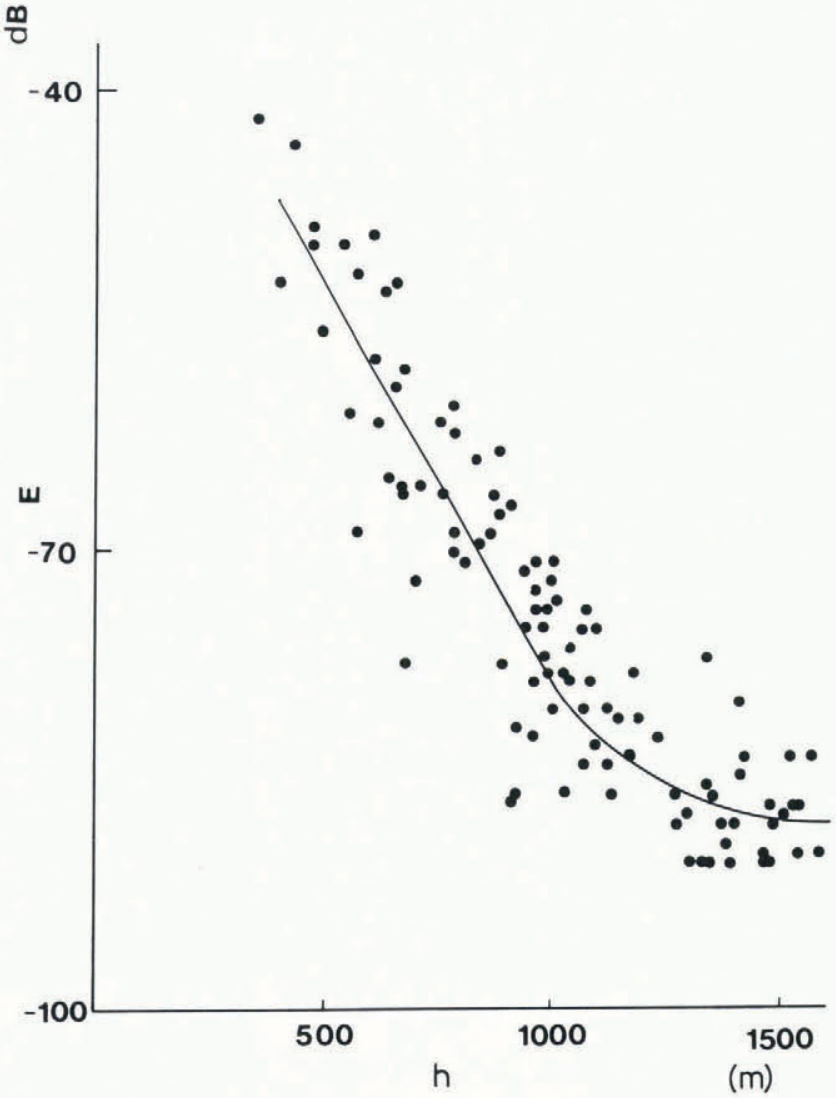

뭉

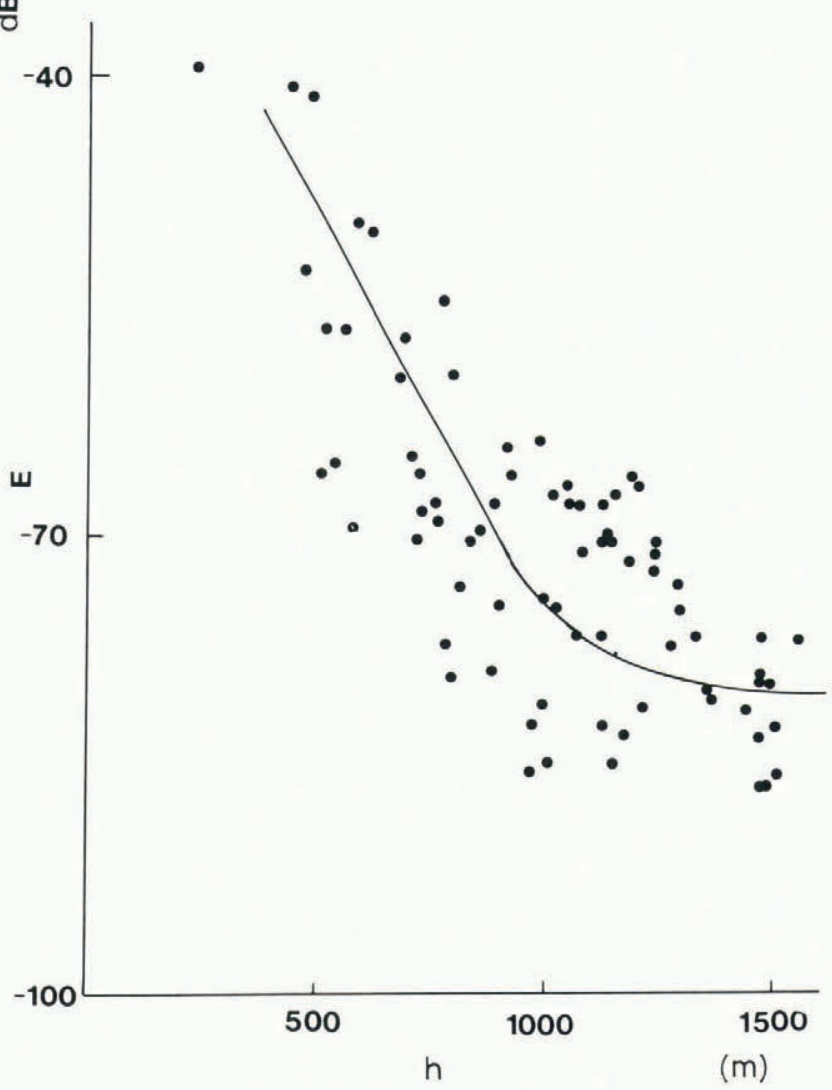

Fig.5a. Relationship between $\mathrm{E}$ and h, flight 1. b. Relationship between $\mathrm{E}$ and $\mathrm{h}$, flight 5 . 
than $\mathrm{E}$ in the neighbouring area. At $\mathrm{A}$ in Fig.6 there is a mountain at $\mathrm{A}$ in Fig. 4 and at $\mathrm{C}$ in Fig. 6 there is a ridge from $C^{\prime}$ to $C^{\prime \prime}$ in Fig.4. Down-stream of $A$ and $C$ in Fig.6 there are areas, D and F, with high E. However, in the down-stream area, B', in Fig.6 of the highest mountain $\mathrm{B}$ in Fig.4, $\mathrm{E}$ is low as shown in Fig.6 and there is no high $E$ area such as $D$ and $F$.

In Fig.6 there is a area of low $\mathrm{E}$ values, $\mathrm{G}$, in the main flow area in the Shirase Glacier drainage basin.

\section{DISCUSSION}

The reflection of radio-echo energy may be affected by the properties of the bedrock and the roughness of the bedrock surface. It is impossible, however, to investigate these factors under a thick ice sheet. When $h$ is less than $1000 \mathrm{~m}$, the relationship between $\mathrm{E}$ and $\mathrm{h}$ is given by approximately the same equation as in the sounding area.

Yoshida and others (1987) have found that echo intensity depends upon the angle between the direction of the ice flow and the aerial orientation. When they are parallel, the echo intensity is strong. In this survey, the direction of the aerials is the same as the direction of the aircraft long axis, which varied with wind direction and wind velocity during flight. It is conceivable, therefore, that the influence of the aerial direction is negligibly small in this survey.

If the properties of the bedrock and its surface roughness are uniform, a possible explanation of the differences in $\mathrm{E}$ is that the echo strength in the Shirase Glacier drainage basin is affected by the presence of water at the base. Outside of the basin, ice is frozen to the bedrock.

At $\mathrm{A}$ in Fig.4 there is a subglacial mountain with an ice thickness of about $1200 \mathrm{~m}$. The average temperature at the ice surface at this point is about $-30^{\circ} \mathrm{C}$, given that the average temperature gradient with elevation is $-1.3^{\circ} \mathrm{C} / 100 \mathrm{~m}$ at Mizuho Plateau (Satow 1978). The flow velocity has not been measured but is estimated to be $30 \mathrm{~m} \mathrm{a}^{-1}$. The accumulation rate is $100-200 \mathrm{~mm} \mathrm{a}^{-1}$. Based on these data, temperature calculations carried out by Nishio and Mae (1979), the basal temperature is about $-10^{\circ}--15^{\circ} \mathrm{C}$, and matches with the low value of $\mathrm{E}$.

Since the flow velocity along the ridge from $\mathrm{C}^{\prime}$ to $\mathrm{C}^{\prime \prime}$ is less than the velocity of the main flow area of the Shirase Glacier drainage basin (Naruse 1978), it is reasonable to suppose that the basal sliding velocity is zero and the basal ice is frozen to the bedrock.

$\mathrm{E}$ is also low around the mountain $\mathrm{B}$ and in the down-stream area of $\mathrm{B}$. Although $\mathrm{E}$ becomes higher in the down-stream area of low B in the Shirase Glacier drainage basin, there is no high area such as D and F in Fig.6 in the down-stream area of $B$. This suggests the basal ice is frozen to bedrock.

As shown in Fig.6, a wide, curved valley extends from Shirase Glacier towards Mizuho Station, where the elevation of the bedrock is approximately $150 \mathrm{~m}$ above sea-level. Elsewhere in the sounded area the bedrock elevation is

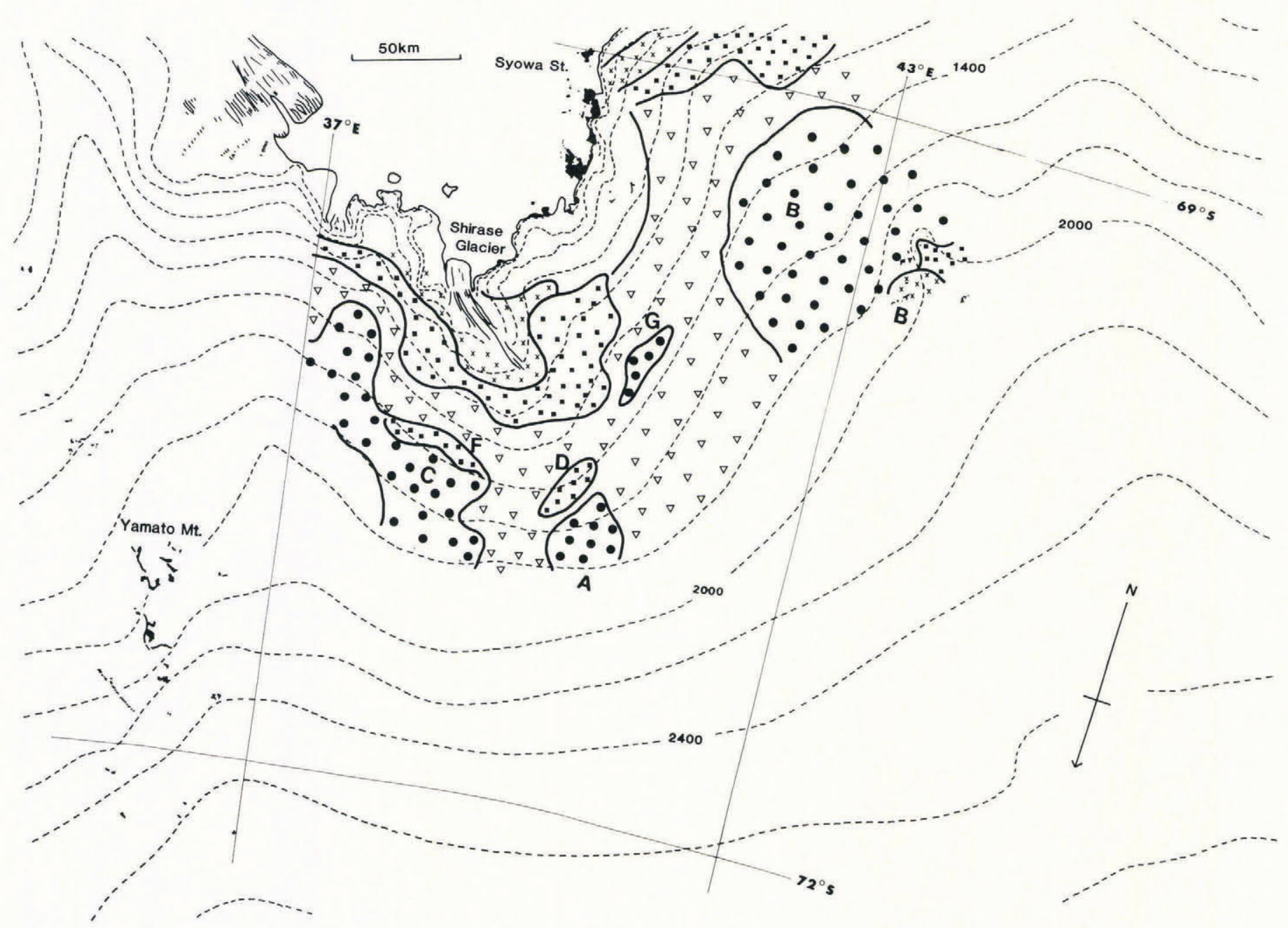

Fig.6. Map of the bedrock reflection coefficient. $\mathrm{x},-40 \mathrm{~dB}>\mathrm{E}>-60 \mathrm{~dB} ; \mathbf{m},-60 \mathrm{~dB}>\mathrm{E}>-70 \mathrm{~dB}$; $\Delta,-70 \mathrm{~dB}>\mathrm{E}>-80 \mathrm{~dB} ; \bullet, \mathrm{E}<-80 \mathrm{~dB}$. 
about $500 \mathrm{~m}$ above sea-level. According to radio echosounding conducted on oversnow traverses (National Institute of Polar Research 1985; Yoshida and others 1987), a high plateau $(500-1000 \mathrm{~m})$ extends further inland.

Mae (1979a, b) and Mae and Naruse (1978) proposed that the basal ice is wet along the trilateration network in the Shirase Glacier drainage basin (Fig.1) and such a wet base is related to basal sliding of about $10 \mathrm{~m} \mathrm{a}^{-1}$ and an ice-sheet thinning rate of $700 \mathrm{~m} \mathrm{a}^{-1}$. Mae $(1979 \mathrm{a}, \mathrm{b})$ and Mae (1982) suggested that the area of wet basal ice (approximately the same area as the region of ice-sheet thinning) expanded in size a few hundred years ago. This idea of disequilibrium is supported by the profile of basal shear stress, $\tau_{\mathrm{b}}$, along the flow line in the Shirase Glacier drainage basin which displays characteristics similar to those of surging glaciers (Mae 1979a, b; Mae 1982). Mae (1979a, b) estimated that $\tau_{\mathrm{b}}$ reached a maximum of about $180 \mathrm{kPa}$ in the region between the boundary of this sounding area and the trilateration network.

If such an hypothesis is correct, the ice-sheet thinning must take place in the down-stream area of the Shirase Glacier drainage basin. Although no direct proof of this hypothesis is available, it is reasonable to consider that the wet basal zone expanded from Shirase Glacier to the relatively low area of bedrock surface which is surrounded by the $500 \mathrm{~m}$ high plateau. At present, the mechanism of formation of the wet base and its expansion is not clear, but it is important for understanding the historical variations of the ice sheet in this area.

The low values of the reflection coefficient at $G$ in the Shirase Glacier drainage basin are difficult to explain as the bedrock surface is only about $100 \mathrm{~m}$ higher than the surrounding area; this is insufficient evidence to suggest that the base is frozen to the bedrock.

\section{ACKNOWLEDGEMENT}

This study is partly supported by a Grant-in-Aid to Scientific Research of the Ministry of Education, Science and Culture, Japan. This is a contribution to the Glaciological Research Programme in east Queen Maud Land, Antarctica, by JARE.

\section{REFERENCES}

Mae S 1979[a] The basal sliding of a thinning ice sheet, Mizuho Plateau, East Antarctica. Journal of Glaciology 24(90): $53-61$

Mae S 1979[b] The recent variation of ice sheet in Mizuho Plateau. Memoirs of National Institute of Polar Research. Special Issue 14: 1-7

Mae S 1982 Hyo-Sho no dorikigaku [Dynamics of ice sheet]. In Kori to yuki [Ice and snow]. Tokyo, National Institute of Polar Research: 117-163

Mae S 1986 Radio echo sounding in the Shirase Glacier drainage basin. Antarctic Record 30(1): 11-18

Mae S, Naruse R 1978 Possible causes of ice sheet thinning in the Mizuho Plateau. Nature 273(5660): 291-292

Naruse R 1978 Surface flow and strain of the ice sheet measured by a triangulation chain in Mizuho Plateau. Memoirs of National Institute of Polar Research. Special Issue 7: $198-226$

National Institute of Polar Research 1985 Data of Antarctic research. Tokyo, National Institute of Polar Research

Nishio F, Mae S 1979 Temperature profile in the bare ice area near the Yamato Mountains, Antarctica. Memoirs of National Institute of Polar Research. Special Issue 12: 25-37

Robin G de Q, Evans S, Bailey J T 1969 Interpretation of radio echo sounding in polar ice sheets. Geophysical Transactions of the Royal Society of London Ser A 265(1166): 437-505

Satow K 1978 Distribution of $10 \mathrm{~m}$ snow temperatures in Mizuho Plateau. Memoirs of National Institute of Polar Research. Special Issue 7: 63-71

Wada M, Mae S 1981 Airborne radio echo sounding on the Shirase Glacier and its drainage basin, East Antarctica. Antarctic Record 72: 16-25
Wada M, Yamanouchi T, Mae S 1982 Radio echo-sounding of Shirase Glacier and the Yamato Mountains area. Annals of Glaciology 3: 312-315

Yoshida M, Yamashita K, Mae S 1987 Bottom topography and internal layers in east Dronning Maud Land, East Antarctica, from $179 \mathrm{MHz}$ radio echo-sounding. Annals of Glaciology 9: 221-224 